\title{
Fetal tissue transplantation: can it be morally insulated from abortion?
}

\author{
Carson Strong University of Tennessee, Memphis, USA
}

\section{Author's abstract}

Ethical controversy over transplantation of human fetal tissue has arisen because the source of tissue is induced abortions. Opposition to such transplants has been based on various arguments, including the following: rightful informed consent cannot be obtained for use of fetal tissue from induced abortions, and fetal tissue transplantation might result in an increase in the number of abortions. These arguments were not accepted by the National Institutes of Health (NIH) Human Fetal Tissue Transplantation Research Panel. The majority opinion of the panel stated that abortion and fetal tissue use are entirely separate issues, and that tissue use is ethically acceptable because it can be morally insulated from the issue of abortion. In support of this view, panel members and others have replied to the arguments put forward by opponents of fetal tissue use. However, replies to the two arguments mentioned above have been unsatisfactory, and the shortcomings of those replies are identified herein. Examination of the arguments pro and con suggests that fetal tissue use cannot be completely insulated from the issue of abortion. Thus, in seeking an ethical justification for fetal tissue transplantation we must consider reasons other than those put forward by the NIH panel. In this paper it is argued that whatever wrong is involved in using fetal tissue from induced abortions must be balanced against the benefits for patients, and it is on this basis that fetal tissue transplantation can be ethically justified.

In recent years, transplantation of fetal tissue has emerged as a possible approach to the treatment of a variety of human diseases. One area of research that seems promising involves the treatment of Parkinson's disease. Animal models of Parkinson's disease can be produced by injecting neurotoxins into the substantia nigra of the midbrain, selectively destroying dopamine-producing cells (1). Monkeys and rats with such lesions have been treated by transplanting fetal substantia nigra into the brain, with remarkable results. The transplanted tissue survives (2), its neurons grow into host tissue (3-5), and in some cases there has been

\section{Key words}

Fetal tissue transplantation; medical ethics; fetus; transplantation; fetal research. significant reversal of symptoms of the drug-induced disease $(6,7)$.

In 1988, researchers in Mexico reported clinical transplantation of human fetal tissue into the brains of patients with Parkinson's disease (8). Fetal substantia nigra was transplanted into the caudate nucleus of a fifty-year-old man with a nine-year history of disease. $\mathrm{He}$ was suffering from severe symptoms with predominance of rigidity and tremor. At three months follow-up there was considerable improvement in his condition (9). Rigidity was imperceptible, and akinesia was absent. He was self-sufficient in most personal activities and could use lower doses of medications.

More recently, Swedish researchers reported success in transplanting fetal substantia nigra into the left putamen of a forty-nine-year-old man who had had Parkinson's disease since 1977 (10). He had had severe rigidity, hypokinetic movements, and a moderate tremor in the right arm, with less marked symptoms in the left arm and legs. Following surgery, there were clinically significant improvements in the patient's condition, including improved mobility. By three months after surgery, the rigidity had almost completely disappeared. Moreover, positron emission tomography scanning five months after surgery showed that the grafted tissue survived, and thus supported the view that the clinical improvements were due to dopamine production resulting from the graft.

To date, at least eight cases of human fetal tissue transplantation for patients with Parkinson's disease have been reported worldwide (11-14). However, the results overall have been mixed, with no improvement for some patients.

Another area of research involves treatment of diabetes mellitus. Transplantation of fetal pancreatic tissue has reversed drug-induced diabetes in mice and rats (15). Initial clinical studies have shown that human fetal pancreatic tissue survives in the human host (15). Fetal tissue also has been transplanted in the treatment of DiGeorge's syndrome, aplastic anaemia, leukaemia, and severe combined immunodeficiency. Other conditions that animal research suggests might be treatable by fetal tissue transplantation include Alzheimer's disease, Huntington's disease, spinal cord injury, and neuroendocrine deficiencies (16). 
At present, guarded optimism over fetal tissue transplantation seems reasonable. Although favourable results were reported in the two cases discussed above, in a similar type of surgery involving grafts of the patient's own adrenal medulla tissue into the brain clinically significant neurological side-effects have been reported (17-19). Further research and confirmation is needed before the benefits and risks of fetal tissue transplantation can be adequately assessed.

The ethics of fetal tissue transplantation was recently debated by the National Institutes of Health (NIH) Human Fetal Tissue Transplantation Research Panel. The panel was established in 1988 after the Assistant Secretary for Health issued a moratorium on funding of research using fetal tissue $(20,21)$. The charge to the panel was to examine the ethical issues and advise NIH on whether such research should be supported by government funds.

Ethical controversy has arisen because the source of fetal tissue is induced abortions. Tissue from spontaneous abortions is generally considered unsatisfactory because of the high rate of fetal pathology, such as chromosomal abnormalities and viral infections, as well as anoxia due to the delay between death of the fetus and expulsion from the uterus (22-24). Opposition to use of fetal tissue is based on the view that abortion is wrong and that tissue use is tied to the morality of abortion. Leading spokesmen for this view have been Burtchaell and Bopp, NIH panel members who gave dissenting arguments to the recommendations of the panel majority. One of Burtchaell's arguments is that rightful informed consent cannot be given for donation of fetal tissue from induced abortions (25). He claims that informed consent for use of tissue is important because of our views concerning respectful treatment of human cadavers. He points out that when we remove body parts to further our own purposes respect for the deceased requires consent, either by the donor prior to death or by one who has moral authority to serve as guardian of the deceased person's remains. Thus, to use Burtchaell's example, to utilise the cadaver of a derelict without consent in order to study anatomy is to fail to accord the full respect that is normally given to human cadavers. If one assumes, as Burtchaell and other abortion opponents do, that fetuses have the moral status of persons, then the problem in using fetal tissue is that the individual who would ordinarily serve as guardian of the remains, the mother of the fetus, has made a decision resulting in the fetus's destruction. Burtchaell asserts that in making such a decision the mother forfeits her moral authority to donate the fetal remains. He argues that we would make a similar judgement if, for example, a man were to kill his wife. He would be morally disqualified from acting as executor of her estate, and it would be inappropriate to vest in him the right to donate her organs for transplantation. For similar reasons, the doctor who performs the abortion could not appropriately serve as guardian of the fetal remains. A policy of allowing the father of the fetus to authorise donation would also be unaccepable, because in many cases the father either is unavailable or concurs with the abortion. Moreover, agents of the government (such as coroners) could not legitimately give consent because in permitting abortions the government forfeits any moral claim it might have to serve as guardian of fetal remains. Thus, according to Burtchaell there is no one in a moral position to provide authorisation of the use of fetal tissue for research or transplantation.

Another argument by Burtchaell and Bopp is that fetal tissue transplantation will increase the number of abortions, for several reasons (16). First, abortions might be regarded more favourably by the general public if there are significant benefits from transplantation. If so, a further entrenchment of the institution of abortion could occur. Second, for some women considering abortion who are particularly ambivalent about the decision, the prospect of benefiting others through fetal tissue transplantation might tip the balance in favour of having the abortion .

These arguments were not accepted by the majority of the 21-member NIH panel. In its report, the panel concluded that it is acceptable public policy to support transplant research using fetal tissue. Part of the panel's defence of that conclusion was the claim that even if abortion is immoral, the fetal tissue obtained can ethically be used for research and transplantation (16). This claim was based on the view that abortion and fetal tissue use are entirely separable issues and that tissue use therefore can be ethically isolated from any immorality associated with the source of the tissue $(16,26,27)$. To help ensure that tissue use would be morally insulated from abortions, the panel included the following among its recommended guidelines (16):

(a) The decision to terminate a pregnancy and the procedures of abortion should be kept independent from the retrieval and use of fetal tissue.

(b) Payments and other forms of remuneration and compensation associated with the procurement of fetal tissue should be prohibited, except payment for reasonable expenses occasioned by the actual retrieval, storage, preparation, and transportation of the tissues. (c) The decision and consent to abort must precede discussion of the possible use of the fetal tissue and any request for such consent as might be required for that use.

(d) The pregnant woman should be prohibited from designating the transplant-recipient of the fetal tissue. (e) Anonymity between donor and recipient should be maintained, so that the donor does not know who will receive the tissue, and the identity of the donor is concealed from the recipient and transplant team.

(f) The timing and method of abortion should not be influenced by the potential uses of fetal tissue for transplantation or medical research.

The panel's view that the issues can be kept separate by 
following appropriate guidelines is initially tempting, for several reasons. First, it avoids the need to take a definite position on the abortion issue. Thus, the ethics of fetal tissue transplantation becomes more straightforward than it would be if it were inseparable from the complex issue of abortion. Second, it seeks a broad consensus based on the idea that, regardless of one's views on abortion, one should consider fetal tissue transplantation to be ethically acceptable provided that it is regulated in an appropriate manner. In support of this approach, replies to the arguments of Burtchaell and Bopp were put forward in the panel report itself (16), by a panel member in other publications $(28,29)$, and by another commentator (30).

However, those replies have failed to refute the above-mentioned arguments of Burtchaell and Bopp and their basic position that the ethical issues of abortion and fetal tissue use are unavoidably intertwined. In order to see this, let us examine those replies. Freedman (30) has argued that the analogy with derelicts is not apt, because using the cadavers of derelicts to study anatomy is less respectful than the burial they would otherwise receive. By contrast, fetal tissue is usually disposed of as organic waste. In Freedman's view, such disposal is substantially less respectful toward fetal remains than its use as a source of transplanted material. A better analogy, Freedman suggests, is a hypothetical case in which a patient urgently requires some blood factor. The only available sample is found in the pathology lab, but the label identifying the person from whom the blood factor was extracted is missing. Thus, it is not possible to contact that person in order to obtain consent for use of the blood factor. Moreover, if the sample is not given to the patient it will be discarded. Freedman claims that this is a case in which we would be ethically justified in using the sample, illustrating that consent is not necessary. However, Freedman's arguments are not persuasive. Not all of a fetus's remains will necessarily be retrieved for use in research and transplantation. Much of the tissue will, in many cases, be disposed of, in the usual ways. It is not at all clear that using some of a fetus's remains for research and disposing of the rest is more respectful than disposing of it all. The case involving blood factor is not a good analogy because it does not involve removal of body parts from cadaveric remains. It misses the point that Burtchaell's argument is based on views about how we should treat dead human bodies. The example could be modified to involve removing and using cadaveric body parts, but then it would be much less clear that the parts should be utilised. After all, many would oppose the removal of organs from a brain-dead individual for transplantation without proper consent. Such attitudes are in fact reflected in the Uniform Anatomical Gift Act, which has been enacted into law in every State in the United States and in the District of Columbia (31). This law authorises removal of organs from cadavers, but only if consent is given by the patient prior to death or by next-of-kin.

Robertson (28) has responded to Burtchaell and Bopp by arguing that respectful treatment of human $\stackrel{?}{+}$ cadavers does not require consent. Rather, the respectfulness of treatment depends only on what is actually done with the cadaver. In defending this view, $\frac{\bar{D}}{\square}$ he claims that autopsies for scientific or law $\mathscr{\perp}$ enforcement purposes are not undignified, even though next-of-kin might object. He also states that $\vec{\circ}$ laws in twelve states permit corneas to be removed for ? transplant without consent of next-of-kin, with no loss of human dignity. However, replies can be made to these arguments. To begin, it is not clear that autopsies for scientific purposes in face of objections from nextof-kin are fully respectful. American law holds that, aside from coroner's cases, the consent of next-of-kin is required prior to autopsy, regardless of whether the purpose is scientific (32). Doctors who perform private autopsies without consent are at risk of liability (32). The purpose of such laws, in part at least, presumably is to promote treatment of cadavers that is consistent with the wishes of the deceased and the views of the $\vec{\oplus}$ decedent's family concerning respectful treatment of $\bullet$ the body. Admittedly, some States authorise autopsies despite family objections in certain cases involving suspected infectious diseases (33). However, the existence of such laws does not demonstrate that autopsies for scientific purposes over the objections of the family are respectful. Rather, such laws might be defended on the grounds that the disrespect that would be involved can sometimes be outweighed by other moral considerations, such as a compelling interest in public health. Similar considerations apply to autopsies for law enforcement purposes and to removal of corneas. In law enforcement cases, autopsies are authorised because there is a public interest at stake, often involving suspected foul play $(33,34)$. Here the overriding considerations are protection of the public and promotion of criminal justice (34). The laws in question permitting cornea removal seem to involve a balancing of the diminution of respect associated with removal of corneas without consent of next-of-kin against the therapeutic benefits to be obtained. It $\tilde{N}$ might be argued that the diminution of respect in such $N$ cases is relatively small, for several reasons. First, the laws apply only to situations in which the coroner or medical examiner is authorised to assume temporary custodianship of the body for the purpose of performing autopsy (35). Second, the 1987 revision of the Uniform Anatomical Gift Act includes a requirement that in such cases reasonable efforts be made to locate the next of kin and that tissues, including corneas, be removed without consent only if such efforts are unsuccessful. To date, six States have incorporated such a requirement into their laws concerning the custody of cadavers by coroners or similar officials (36). Third, the laws in question do not permit removal if the decedent or family members are

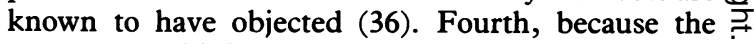
corneas would be removed during this period of 
custodianship, their removal would normally create no interference with burial plans or other arrangements the family might make for disposition of the body. Moreover, cosmetic restoration can be provided if needed, so that the appearance that the body would have during a funeral is not altered. Thus, it might be argued that removal of corneas without consent of donor or family in such cases is justifiable because the diminution of respect that is involved is minor and the potential benefits to those in need of corneas is significant.

These replies to Freedman and Robertson suggest the following conclusion: if human fetal cadavers deserve the same respect as adult cadavers, then consent for use of fetal remains by one morally authorised to give it is required, and this requirement may be lifted only if there are overriding ethical considerations.

Robertson has also responded to the argument that fetal tissue transplantation will increase the number of abortions $(28,29)$. With regard to further entrenchment of abortion, Robertson points out that laws permitting abortions are based on the wide disagreement that exists over the status of early fetuses. Concerns about fetal interests and the right to selfdetermination of women are more central to the controversy than possible benefits of transplantation. Robertson claims that if a majority believed that fetuses should be respected as persons despite the burdens placed on pregnant women, then the possible benefits of fetal tissue transplants would not prevent a change in the legality of abortion (29). Concerning individual abortion decisions, Robertson points out that the feared impact is speculative. Even if therapies prove successful, the prospect of benefiting others might tip the balance in only a small number of cases. Moreover, a small increase in abortions would not make use of fetal tissue unacceptable. As he points out, highway engineering, drug licensing, and gun sales will lead to some loss of life as a result of the activity. The risk of losing some lives is not sufficient to stop those projects when the number of deaths is not substantial, the activity serves worthy goals, and reasonable steps to minimise the loss have been taken (16). Similarly, forbidding fetal tissue transplants is not justifiable just because there would be some increase in the number of abortions.

However, Robertson's replies fail to support the view that fetal tissue use can be morally isolated from abortions. His response to the entrenchment argument is itself speculative, as almost any prediction about these matters is bound to be. He assumes that even if fetal tissue transplantation were highly successful in treating a variety of conditions, it would not influence public opinion about abortions. It would seem more reasonable to acknowledge the uncertainty about how attitudes would be affected. Moreover, a reasonable judgement that there might be a further entrenchment of the institution of abortion is all that is needed to establish that the issues of tissue use and abortion are not completely insulated from each other. If further entrenchment is bad and has a chance of occurring, then the potential harm it represents must be balanced against the potential benefits of the transplantation. To say that the issues are isolated, on the other hand, implies that no balancing is needed.

Robertson's reply to the argument concerning individual abortion decisions seems implicitly to acknowledge that the issues are not morally isolated. He suggests that the deaths associated with an activity like highway engineering are an evil that sometimes is outweighed, in part, by the worthy goals of the activity. Thus, his analogy implies that a small increase in the number of abortions is an evil that would be outweighed, in part, by the benefits of fetal tissue transplantation. But to carry out this balancing is to acknowledge that there is an ethical conflict between the benefits of tissue use and respect for fetal life, not an isolation of the two.

Thus, the view that use of fetal tissue can be fully insulated from the issue of abortion is unfounded. It is not true that, regardless of one's views on abortion and the moral status of fetal remains, one can consistently consider use of fetal tissue to be morally acceptable.

One might ask how a prestigious national panel of experts could have adopted such an untenable view. Perhaps the majority opinion was clouded by the issue of whether those who perform research with fetal tissue are accomplices to the abortions that produce the tissue. A third argument of Burtchaell and Bopp had been that there is such complicity and that researchers therefore inevitably have dirty hands (16). The panel majority was quick to respond to this argument, pointing out that researchers would play no causal role in the abortions, that they were merely using tissue that would otherwise be discarded (16). This response is bolstered by an analogy with a brain-dead, adult, murder-victim whose organs are removed for transplantation. We certainly would not say that the surgeon who removes the organs is an accomplice to the murder. Similarly, the researcher who makes use of whatever fetal tissue is available has no complicity with the abortion (37). The majority's response to the argument in question appeared satisfactory. With regard to the issue of complicity, fetal tissue use is morally isolated from abortion, provided that the panel's guidelines are followed. The complicity argument was inflammatory, however, with Burtchaell and Bopp going as far as comparing fetal tissue research with Nazi atrocities. At least some members regarded these comparisons as outrageous, as evidenced by comments in the report (16). Perhaps influenced by its own vehement rejection of the complicity argument, the majority went too far in claiming that the issues of abortion and fetal tissue use are completely isolated.

The fact that the issues are not totally isolated does not imply, of course, that use of fetal tissue in research and transplantation is wrong. It means, however, that in seeking an ethical justification for such activities we 
must turn to reasons other than those put forward by the NIH panel. If such tissue use is ethical, then it is important to state explicitly why it is so. One must argue either that there is nothing morally problematic about abortion, or that whatever wrong is involved in using tissue from induced abortions is morally outweighed by other considerations.

It is not plausible to maintain that there is nothing morally problematic about abortion. At the very least, one can argue that the potential of the fetus to become a person gives abortion some moral significance. However, it can be argued that whatever wrong might be involved in use of fetal tissue obtained from induced abortions is outweighed by the potential benefits to patients. This moral balancing involves two basic factors: the degree of wrongness in using the tissue; and the degree and likelihood of potential benefits to patients resulting from tissue use. The less the wrongness and the greater and more likely the benefits, the stronger is the argument that fetal tissue transplantation is ethically justifiable.

Several considerations suggest that the degree of wrongness is relatively low. First, it can be argued that fetuses in early gestation are not persons. One such argument is based on the implausibility of holding that they are the type of individuals that can have rights. It has been persuasively argued that a prerequisite of having rights is that one be a type of individual that can have moral interests (38). Moreover, it is not reasonable to think that individuals lacking desires, cognitive awareness, and perceptions have interests (38). With regard to substantia nigra transplants, tissue would be obtained from fetuses at approximately 8-11 weeks gestational age $(13,16)$. Although the stage of gestation at which fetal perception begins is not clear, current research suggests that it is considerably later than the 8-11 week period. The brain structures that give rise to such experiences are not sufficiently developed until later (39). For example, thalamocortical connections necessary for pain perception do not seem to be established until some time between 20 and 24 weeks of gestation (40). For these reasons, the claim that fetuses at $8-11$ weeks gestational age have rights is questionable. And if they do not have rights, then they cannot be persons, because part of what it means to say that one is a person is that one has a right to life.

It might be objected that interests the fetus will have in the future can create rights that the fetus possesses now (38). On this basis one might claim, for example, that the fetus has a right not to be subjected to highrisk, non-therapeutic research because at some future time the fetus will have an interest in being free of harms that might occur through such research. Even if we were to accept this objection, however, it would not follow that the fetus now has a right to life. If the fetus now is killed, there will be no future individual having interests. Because an individual with interests never exists, it is difficult to claim that a right to life - or any right, for that matter - is violated by killing the fetus.
Second, a lack of personhood status of the fetuses in question has implications for the argument concerning informed consent. If these fetuses are not persons, then it is doubtful that respectful treatment of the fetal remains involves exactly the same requirements as respectful treatment of adult cadavers. Specifically, although consent for use of adult cadavers is necessary, it is not clear that it is needed for respectful use of fetal tissue early in gestation. Consent for use of fetal tissue seems to be required, rather, in order to protect the interests of the woman having the abortion (29). Third, a lack of personhood status has implications for the argument that the number of abortions will increase. If fetuses early in gestation lack rights and interests, then an increase in abortions does not have the same degree of moral significance that it would have if fetuses had rights and interests that needed protection. These considerations do not imply that there is nothing at all morally problematic about use of tissue from induced abortions. If human fetuses in early gestation have some degree of moral standing, then an increase in abortions would seem to be morally undesirable to some degree. However, the above considerations suggest that the wrongness of using early-gestation fetal tissue is not nearly as great as that claimed by Burtchaell and Bopp.

Moreover, it can be argued that the potential for benefit from fetal tissue transplantation is morally significant. Those who might benefit - sufferers of Parkinson's disease, diabetes, and other disabling disorders - are indeed persons, a fact that is absolutely without controversy. Thus, if there is benefit to those individuals, it will undoubtedly have moral significance because it is a benefit to persons. Moreover, there is a reasonable chance that there will be at least some benefit from going forward with this area of clinical research. Even if it turns out that fetal tissue transplantation does not provide effective treatments, knowledge will be gained about the human body, disease, and therapeutic interventions. Such knowledge often has a way of eventually contributing, in greater or less degree, to the development of useful applications. In addition, if therapies prove effective, the degree of the benefits might be great.

In summary, transplantation and research involving human fetal tissue appear ethically justifiable because the degree of wrongness that might be involved seems relatively low, no rights would be violated (assuming the woman having the abortion gives informed consent to use of the fetal tissue, and other pertinent guidelines and laws are followed), at least some benefit is reasonably expected, and great benefits are possible.

Nevertheless, research involving fetal tissue should proceed with caution. The potential benefits to the tissue recipient are still speculative, but risks exist. Protection of these research subjects should be of uppermost concern. Published recommendations include the following: more animal studies are needed $(41,42)$; clinical research should be conducted at only highly specialised centres $(24,43)$; and research protocols should be carefully reviewed (44). 
In order to defend a view concerning the ethics of fetal tissue transplantation, it seems necessary to take a position concerning the moral status of early-gestation fetuses, as is done in the above argument. Moreover, the above approach helps explain why it is appropriate to adopt guidelines that provide greater insulation between research and abortions. It is not desirable to increase the number of abortions or to use tissue in a manner that some find offensive. Such features of fetal tissue use can be countenanced only if they are outweighed by other moral considerations. Other things being equal, it is morally preferable to minimise these effects. The greater the insulation produced by guidelines, the less pronounced will be any increase in the number of abortions. Moreover, the health interests of the woman having an abortion are protected by insulating procedures such as not allowing the timing or method of abortion to be influenced by the research uses of the tissue. In addition, there is a consensus that certain activities should be flatly proscribed, such as abortions for the sole purpose of obtaining the tissue. This makes it appropriate to have additional insulating guidelines, such as a rule that the woman having the abortion may not designate the recipient of the tissue. Appropriate insulating guidelines have been recommended by several committees in addition to the NIH panel (45-48).

It might be objected that the above argument is utilitarian, that it approves the wronging of fetuses in order to produce a net benefit overall. However, this objection fails to consider that an essential feature of the argument is that no rights would be violated, provided that relevant guidelines and laws are followed. The potential benefits of fetal tissue transplantation are a compelling consideration only because it is reasonable to think that the research can be performed without violating rights. To appeal to benefits in situations in which no rights are violated does not make one a utilitarian.

For those who strongly oppose abortion, these arguments will be rejected. The arguments of Burtchaell and Bopp help explain why many who consider abortion to be killing persons might disapprove of fetal tissue use. The United States Assistant Secretary for Health in the Department of Health and Human Services, Dr James Mason, recently announced that the ban on federal funding will be continued indefinitely (49). Thus, the American administration continues to be strongly influenced by anti-abortion views. We should expect fetal tissue transplantation to continue being as controversial as the abortion issue itself.

\section{Acknowledgement}

I am grateful to John Robertson for critical comments on an earlier version of this paper. This does not imply that he endorses all the views that I express herein.
Carson Strong PhD is Associate Professor in the Department of Human Values and Ethics, College of Medicine, University of Tennessee, Memphis, Tennessee, USA.

\section{References}

(1) Hoffer B J, Granholme A, Stevens J O, Olson L. Catecholamine-containing grafts in Parkinsonism: past and present. Clinical research 1988; 36: 189-195.

(2) Freed W J, Perlow M J, Karoum F, et al. Restoration of dopaminergic function by grafting of fetal rat substantia nigra to the caudate nucleus: long-term behavioral, biochemical, and histological studies. Annals of neurology 1980; 8: 510-519.

(3) Bjorklund A, Stenevi U. Reconstruction of the nigrostriatal dopamine pathway by intracerebral nigral transplants. Brain research 1979; 177: 555-560.

(4) Perlow M J, Freed W J, Hoffer B J, Seiger A, Olson L, Wyatt $R$ J. Brain grafts reduce motor abnormalities produced by destruction of nigrostriatal dopamine system. Science 1979; 204: 643-647.

(5) Sladek J R Jr, Redmond D E Jr, Roth R H. Transplantation of fetal neurons in primates. Clinical research 1988; 36: 200-204.

(6) Bjorklund A, Dunnett S B, Stenevi U, Lewis M E, Iverson $S \mathrm{D}$. Reinnervation of the denervated striatum by substantia nigra transplants: Functional consequences as revealed by pharmacological and sensorimotor testing. Brain research 1980; 199: 307-333.

(7) Redmond D E Jr, Sladek J R Jr, Roth R H, et al. Fetal neuronal grafts in monkeys given methylphenyltetrahydropyridine. Lancet 1986; 1: 11251127.

(8) Madrazo I, Leon V, Torres C, et al. Transplantation of fetal substantia nigra and adrenal medula to the caudate nucleus in two patients with Parkinson's disease. New England journal of medicine 1988; 318: 51.

(9) Madrazo I, Drucker-Colin R. Transplantation of fetal substantia nigra and adrenal medulla to the caudate nucleus in two patients with Parkinson's disease [letter]. New England journal of medicine 1988; 319: 371.

(10) Lindvall O, Brundin P, Widner H, et al. Grafts of fetal dopamine neurons survive and improve motor function in Parkinson's disease. Science 1990; 247: 574-577.

(11) Hitchcock E R, Clough C, Hughes R, Kenny B. Embryos and Parkinson's disease. Lancet 1988; 1: 1274.

(12) Lindvall O, Rehncrona S, Gustavii B, et al. Fetal dopamine-rich mesencephalic grafts in Parkinson's disease. Lancet 1988; 2: 1483-1484.

(13) Lindvall O, Rehncrona S, Brundin P, et al. Human fetal dopamine neurons grafted into the striatum in two patients with severe Parkinson's disease: a detailed account of methodology and a 6-...onth follow-up. Archives of neurology 1989; 46: 615-631.

(14) Merz B. Neurologists join neurosurgeons in urging restraint in Parkinson's surgery. Fournal of the American Medical Association 1989; 261: 2929.

(15) Lafferty K J. Diabetes islet cell transplant research: basic science. In: Consultants to the Advisory Committee to the Director, National Institutes of Health. Report of the Human Fetal Tissue Transplantation Research Panel vol II. Bethesda, Maryland: National Institutes of Health; 1988: D142-D144. 
(16) Consultants to the Advisory Committee to the Director, National Institutes of Health. Report of the Human Fetal Tissue Transplantation Research Panel vol I. Bethesda, Maryland: National Institutes of Health, 1988.

(17) Tanner C M, Goetz C G, Gilley D W. Behavioral aspects of intrastriatal adrenal medulla transplant surgery in Parkinson's disease. Neurology 1988; 38 (suppl 1): 143144.

(18) Olanow C W, Cahill D, Cox C, Werner E, Gauger L. Autotransplantation of adrenal medulla to caudate nucleus in Parkinson's disease. Annals of neurology 1988; 24: 180.

(19) Allen G S, Burns R S, Tulipan N B, Parker R A. Adrenal medullary transplantation to the caudate nucleus in Parkinson's disease. Archives of neurology 1989; 46: 487491.

(20) Consultants to the Advisory Committee to the Director, National Institutes of Health. Report of the Human Fetal Tissue Transplantation Research Panel vol II. Bethesda, Maryland: National Institutes of Health, 1988: B1-B3.

(21) White House against funding of fetal transplants. American medical news 1988 Sept 23: 6.

(22) Fine A. The ethics of fetal tissue transplants. Hastings Center report 1988; 18 : 5-8.

(23) Voss H F. Statement before the Human Fetal Tissue Transplantation Research Panel. In: Consultants to the Advisory Committee to the Director, National Institutes of Health. Report of the Human Fetal Tissue Transplantation Research Panel vol II. Bethesda, Maryland: National Institutes of Health, 1988: D252D265.

(24) Annas G J, Elias S. The politics of transplantation of human fetal tissue. New England journal of medicine 1989; 320: 1079-1082.

(25) Burtchaell J T. Case study: University policy on experimental use of aborted fetal tissue. IRB: review of human subjects research 1988; 10: 7-11.

(26) Gianelli D M. Panel apparently favoring fetal tissue research. American medical news 1988 Oct 7: 3,39.

(27) Marwick C. Fetal tissue study panel nears conclusion. Fournal of the American Medical Association 1988; 260: 3108-3109.

(28) Robertson J A. Fetal tissue transplant research is ethical. IRB: review of human subjects research 1988; 10: 5-8.

(29) Robertson J A. Rights, symbolism, and public policy in fetal tissue transplants. Hastings Center report 1988; 18: 5-12.

(30) Freedman B. The ethics of using human fetal tissue. IRB: review of human subjects research $1988 ; 10: 1-4$.

(31) Uniform Anatomical Gift Act (1968), 8A ULA 30-67. In: Uniform laws annotated. St Paul: West, 1983.

(32) 22A Am jur 2d Dead bodies. Sections 60-66 (1966).
(33) Quay P M. Utilizing the bodies of the dead. Saint Louis University law journal 1984; 28: 889-927.

(34) $18 \mathrm{Am}$ jur 2d Coroners. Section 10 (1939).

(35) Department of Health and Human Services Task Force on Organ Transplantation. Organ transplantation: issues and recommendations. Washington, DC: US Government Printing Office, 1986: 28-29.

(36) Uniform Anatomical Gift Act (1987), 8A ULA (1990 Pocket Part) 2-27. In: Uniform laws annotated. St Paul: West, 1983.

(37) Gillon R. Ethics of fetal brain cell transplants. British medical journal 1988; 296: 1212-1213.

(38) Feinberg J. The rights of animals and unborn generations. In: Blackstone $\mathrm{W} \mathrm{T}$, ed. Philosophy and environmental crisis. Athens, Georgia: University of Georgia Press; 1974: 43-68.

(39) Sumner L W. A third way. In: Feinberg J, ed. The problem of abortion (2nd ed). Belmont, California: Wadsworth Publishing Co, 1984: 71-93.

(40) Anand K J S, Hickey P R. Pain and its effects in the human neonate and fetus. New England journal of medicine 1987; 317: 1321-1329.

(41) Joynt R J, Gash D M. Neural transplants: are we ready? Annals of neurology 1987; 22: 455-456.

(42) Sladek J R Jr, Shoulson I. Neural transplantation: a call for patience rather than patients. Science 1988; 240: 1386-1388.

(43) Lewin R. Caution continues over transplants. Science 1988; 242: 1379.

(44) Mahowald M B, Areen J, Hoffer B J, et al. Transplantation of neural tissue from fetuses. Science 1987; 235: 1307-1308.

(45) National Health and Medical Research Council. Ethics in medical research involving the human fetus and human fetal tissue. Medical journal of Australia 1984; 140: 610-620.

(46) Council of Europe, Parliamentary Assembly. Recommendation 1046 (1986) (1) on the use of human embryos and fetuses for diagnostic, therapeutic, scientific, industrial and commercial purposes. Human reproduction 1987; 2: 67-75.

(47) Greely H T, Hamm T, Johnson R, et al. The ethical use of human fetal tissue in medicine. New England journal of medicine 1989 ; 320: 1093-1096.

(48) American Medical Association Council on Scientific Affairs and Council on Ethical and Judicial Affairs. Medical applications of fetal tissue transplantation. Fournal of the American Medical Association 1990; 263: 565-570.

(49) US extends funding ban for research on fetal tissue. The commercial appeal (Memphis). 1989 Nov 2: A2. 